\title{
The impact of writing on curriculum development-a study of personality, Community Development
}

\author{
Gulmira JURABOYEVA ${ }^{1}$, Khadicha TURSUNKULOVA ${ }^{2}$ \\ Samarkand State Institute of Foreign Languages
}

\begin{tabular}{l} 
ARTICLE INFO \\
\hline Article history: \\
Received April 2021 \\
Received in revised form \\
20 April 2021 \\
Accepted 15 May 2021 \\
Available online \\
25 June 2021
\end{tabular}

Keywords:

educational acquisition,

science,

new media,

case study,

approach.

\begin{abstract}
The paper provides case studies of how four school members United Nations agency teach in undergraduate and graduate programs at the colleges of information science promote educational acquisition throughout the course of study. The paper describes the writing assignments in many courses, the objectives of those assignments in enhancing the writing skills of scholars, the pedagogic approaches utilized by the school members and a discussion of the results. Suggestions for assessing student writing will be provided.
\end{abstract}

2181-1415/C) 2021 in Science LLC.

This is an open access article under the Attribution 4.0 International (CC BY 4.0) license (https://creativecommons.org/licenses/by/4.0/deed.ru)

\section{Yozishning o'quv dasturiga ta'siri - shaxs, jamiyat taraqqiyotini o'rganish}

\footnotetext{
Kalit so'zlar:

ta'limni joriy qilish,

fanlar,

yangi OAV,

amaliy mashg'ulot,

yondashuv.
}

\begin{abstract}
ANNOTATSIYA
Mazkur maqola birlashgan Millatlar Tashkilotining "Axborotshunoslik" kollejlarida magistraturagacha va magistratura dasturlarida o'qitishning qanday o'qitishidagi to'rtta maktab agentliklari o'qitish jarayonida o'quv yilida ta'lim olishni rag'batlantirishini ta'minlaydi. Maqolada ko'plab kurslarda yozma topshiriqlar, olimlarning yozish mahoratini oshirishni takomillashtirish, maktab a'zolari tomonidan o'tkazilgan pedagogik yondoshuvlar va natijalar muhokama qilingan. Talaba yozish qobiliyatini baholash bo'yicha takliflar berilgan.
\end{abstract}

\footnotetext{
${ }^{1}$ Student, Samarkand state institute of foreign languages, Samarkand, Uzbekistan.

E-mail: gulmirajuraboyeva@gmail.com.

${ }^{2}$ Student, Samarkand state institute of foreign languages, Samarkand, Uzbekistan.

E-mail: khadichatursunkulova@gmail.com.
} 


\section{Влияние письма на разработку учебной программы - изучение личности, развитие сообщества}

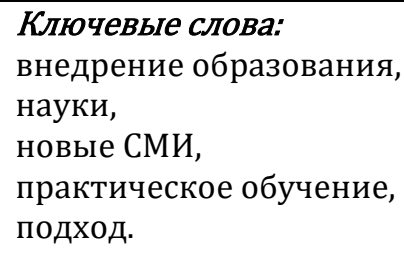

\section{АННОТАЦИЯ}

В этой статье рассказывается о том, как четыре школьных агентства Организации Объединенных Наций поощряют обучение в течение учебного года во время обучения в колледжах «Информатизации», в том числе в программах бакалавриата и магистратуры. В статье обсуждаются письменные задания на многих курсах, улучшение навыков письменности ученых, педагогические подходы и результаты, полученные членами школы. Даны предложения по оценке способности студента к письменности.

\section{INTRODUCTION}

Effective writing may be a talent that's grounded within the psychological feature domain. It involves learning, comprehension, application and synthesis of recent information. From a college member's perspective, writing well entails over adhering to writing conventions.

Writing conjointly encompasses artistic inspiration, problem-solving, reflection and revision that leads to a completed manuscript. From a student's perspective, writing could instead be an effortful and even dread exercise of trying to position thoughts on paper whereas developing mastery over the foundations of writing, like writing system, citation format and descriptive linguistics. Grammar Check

Over the past several years, it has become apparent to the faculty at Indiana University School of Informatics, Indiana University Purdue University Indianapolis (IUPUI) that students entering the undergraduate programs of Media Arts and Science, Informatics and Health Information Administration as well as the Health Informatics graduate program lack the necessary writing skills needed to become successful communicators both during their studies and after graduation. The authors teach in undergraduate, both undergraduate and graduate programs and purely graduate programs, providing a broad perspective on an issue that crosses all disciplines and educational levels. The concern for the writing abilities of students has become more focused with IUPUI's adoption of the Principles of Undergraduate Learning (PULs). The first PUL, Core Communication and Quantitative Skills, encompasses the ability to "express ideas and facts to others effectively in a variety of formats, particularly written, oral, and visual formats". Whatever the reasons may be, the bottom line is that the majority of students do not possess the skills necessary to effectively communicate in a written format that will enable them to become successful upon graduation. There is a significant need for students at all levels not only to be good written communicators, but also to understand the importance of good writing skills. In addition, an important facet of written communication is being able to critically assess the writing of others, particularly at the graduate level as well as in professional programs. 


\section{METHODS}

As educators, the key question becomes: however, will school members teach their students to become effective writers and communicators within the short quantity of your time that there's to move with and influence them? The setting within which today's school students communicate is primarily one in every of texting and email messages. one in every of the most issues with these communication ways is that they'll consider the employment of abbreviations and informal language. Punctuation, capitalization, spelling, organization and flow could also be forgotten in favor of bits and bytes. Also, attributable to the immediacy of those communication ways, there's very little within the means of reflection of either what's received or what's being sent. Making ready students to speak within the planet of labor may be a challenge for educators in educational activity. School members should balance the availability of content whereas modeling skilled communication skills victimization economical tools. However, writing skills should be addressed if school members area unit to adequately prepare students for jobs that involve over marginal levels of responsibility. The subsequent article has three goals.

The first goal is to familiarize the reader with the experiences of four faculty members at Indiana University School of Informatics, IUPUI, in trying to bring students to an acceptable level of writing skill before students complete their degree programs. This will be illustrated through case studies. Second, as part of these case studies, examples of assignments and other approaches that were used to aid the students in developing a higher level of writing ability will be discussed. Finally, this article will provide some suggestions, based on the experiences discussed in each case study, on how written skills could be assessed in undergraduate and graduate courses, including both online and faceto-face courses.

\section{LITERATURE REVIEW}

A study by the American Institutes of Research (Baer, Cook, and Baldi, 2006) surveyed the literacy skills of college graduates of two- and four-year programs, with the results indicating that over half of the students who responded lacked basic skills, such as understanding and executing simple instructions or balancing a checkbook. Students face the responsibility of developing their writing skills, specifically in the area of academic writing. However, it is clear that many students have difficulty with writing for a number of different reasons (Bartlett, 2003; Odell and Swersey, 2003). Another issue is how we measure excellence in writing (Dwyer, Millett, and Payne, 2006; Hacker, Dunlosky, and Graesser, 1998; Zamel and Spack, 1998; Zamel, 1987). Concerns about effective writing among college man and graduate students in instruction are well documented. On the opposite hand, MacArthur (1996) thought that computers might support writing by students with learning disabilities by inserting special stress on applications that went on the far side data processing. He found that the essential processes of transcription and sentence generation, as well as writing system checkers, speech synthesis, word prediction, and synchronic linguistics and elegance checkers provided ample support for writing talents. Stein, Dixon, and Isaacson (1994) suggest that "many writing disabilities may derive from too little time allocated to writing instruction or from writing instruction inadequately designed around the learning needs of many students" (P. 392). Their study reviewed the characteristics of students with learning difficulties and provided recommendations for teaching writing effectively to a broad range of students. The effective techniques cited in their study are: the concept of big ideas, strategies, scaffolding, and review. 


\section{RESULTS AND DISCUSSION}

Trioa (2003) suggests that the problems experienced by students in writing effective are attributable, in part, to their difficulties in executing and regulating the processes which underlie proficient composing, planning and revisions of their work. Another important element in achieving excellence in writing is the reflective process the ability to critique one's own work as well as the work of peers. As outlined by McGuire, Lay and Peters, this reflective aspect of writing is particularly important in the curriculum of professional programs as a method of teaching problem-solving (McGuire, Lay, and Peters, 2009). Holtzman and colleagues (2005), in an article about assessing the writing skills of dental students, noted that "the ability to communicate effectively has been recognized as a hallmark for membership in the learned professions". (Holtzman, Elliot, Biber, and Sanders, 2005, p. 285). Another study found that the formal attention given to writing practice outside of the content covered was apparent in higher education. Cho and Schunn (2007) reported that the National Commission on Writing in American Schools and Colleges (2003) supported this claim. They cited the practice of peer review of student writing, indicating that peer reviews can help instructors spend more time on other aspects of teaching by reducing the instructor's workload associated with writing activities (Cho and Schunn, 2005; Rada, Michailidis, and Wang, 1994). Using several innovative approaches in order to address writing practices among undergraduate and graduate students was implemented by four faculty members at IUPUI. Their work is discussed in the following sections.

There is a right away correlation within the school member's on-line courses between regular participation within the weekly discussion forums and therefore the final course grade. Student engagement in on-line courses is one predictor of student success, therefore this affiliation isn't shocking. In fact, students have reportable that the mixture of weekly discussion forums and podcasts created a way of community that almost replicated what would be found in a very ancient face-to-face course. For functions of this paper, another advantage of the discussion forums is that students are writing each week and are then receiving feedback on their responses. Attributable to the character of the discussion forum queries, the number that students are needed to write down weekly will be substantial. The queries are varied to tell apart student expertise with the subject of the module, their comprehension of the fabric, their ability to use the fabric to varied eventualities, their chance of mistreatment the fabric within their future careers and whether or not there have been problems in the module that they found shocking or attention-grabbing. It's notably attention-grabbing to examine that students are going to be the "first responders" to every weekly discussion forum and to watch once student responses become a lot of strong because the semester progresses. Likewise, the great Final Project conjointly implies that students should apply what they learned throughout the semester to a real-world scenario. By the top of the semester, students World Health Organization have participated frequently within the weekly discussion forums can have already got done a substantial quantity of writing. There conjointly seems to be a correlation between regular versus inconsistent participation in weekly discussion forums and high and low scores on the ultimate Project. this can be somewhat to be expected, since a student World Health Organization is engaged within the course is probably going to be motivated to try to well on each the weekly and therefore the final course necessities. However, it may conjointly indicate that students World Health Organization have reached a precise level of comfort by having to write down weekly don't seem to be as intimidated by the prospect of a comprehensive, essay-style assignment. 
Pedagogical Approach. The pedagogical approach for these categories consisted of the logical steps toward writing an honest analysis paper. So as for every student to attain acceptable results the educational theories of 'Learned by Doing' and art movement were used. Students were able to turn on and construct new information regarding the analysis method because it pertained to their form of writing inside the primary period of the course, students were asked to submit a subject proposal describing their areas of analysis interest. Students were schooled to incorporate a sample reference list of 10-15 references. The subject proposal provided the teacher with a glimpse of meant analysis and gave an illuminating read of every student's current writing skill-level. Students were then given samples of wonderful and poorly written thesis and analysis statements. Students were asked to put in writing 5 samples of hypothesis and/or analysis statements supported their projected analysis topic. So as to interact students during this method, a democratic approach consisting of student peer-reviews was a weekly activity throughout the semester. Once student analysis statements had been approved, students were schooled on a way to develop a top level view for his or her analysis papers.

Grammar Check Re-write Again

The proposed outline for their research papers consisted of the following:

I. Introduction

II. Literature Review

III. Methods

IV. Findings

V. Summary

VI. References

VII. Appendices

VIII. Abstract

Students produced several drafts for each section of the research outline during the semester. Student peer-reviews and instructor feedback were given for each draft submission. In order to review papers effectively, students were given written instructions on the review process, along with a scoring rubric (see Appendix 3). Students were required to create and deliver a PowerPoint presentation as a succinct review of their research efforts. Students were given 15 minutes and expected to present no less than fifteen slides. The final slide in their presentation was to list three "unresolved issues" in the area of research they had selected then ask for questions and comments from their audience.

\section{CONCLUSION}

The paper provided case studies of however four college members United Nations agency teach in collegian and graduate programs at the in colleges of science promote educational acquisition throughout the information. The paper delineates the writing assignments from many graduate and collegian on-line and face-to-face courses, the objectives of those assignments in enhancing the writing skills of scholars, the education approaches utilized by the college members and a discussion of the results. These assignments enclosed analysis papers, weekly discussion forums, "learning by doing" and comprehensive final comes. Many suggestions for assessing student writing were additionally provided, together with review by peers, analysis at varied stages of the assignment, self-reflection and feedback through weekly podcasts. 


\section{REFERENCES:}

1. Bartlett T. (2003). Why Johnny can't write, even though he went to Princeton. Chronicle of Higher Education, 49 (17), A39-A40.

2. Cho K. and Schunn C.D. (2007). Scaffolded writing and rewriting in the discipline: A web-based reciprocal peer review system. Computers \& Education, 48 (3), 409-426.

3. Dwyer C.A., Millett C.M. and Payne D.G. (2006). A culture of evidence: Postsecondary assessment and learning outcomes. Princeton, NJ: Educational Testing Service.

4. Elander J., Harrington K., Norton L., Robinson H. and Reddy P. (2006). Complex skills and academic writing: a review of evidence about the types of learning required to meet core assessment criteria. Assessment \& Evaluation in Higher Education, 31 (1), 71-90.

5. Hacker D.J., Dunlosky J. and Graesser A.C. (1998). Metacognition in educational theory and practice. Mahwah N.J.: Lawrence Erlbaum Associates.

6. Holtzman J.M., Elliot N., Biber C.L. and Sanders R.M. (2005). Computerized assessment of dental student writing skills. Journal of Dental Education, 69 (2), 285-295. 